\title{
TWO NEW SPECIES OF CLAUSILIIDAE (GASTROPODA: PULMONATA) FROM YUNNAN PROVINCE, SOUTHERN CHINA
}

\author{
JOZEF GREGO1 ${ }^{1}$ MiKLÓs SZEKERES ${ }^{2,3 *}$
}

\begin{abstract}
${ }^{1}$ Horná Mičiná 219, SK-97401 Banská Bystrica, Slovakia
${ }^{2}$ Institute of Plant Biology, Biological Research Centre of the Hungarian Academy of Sciences, Temesvári krt. 62, H-6726 Szeged, Hungary (e-mail: szekeres@brc.hu); (1) https://orcid.org/0000-0002-6354-1790 ${ }^{3}$ Zoology Department, Hungarian Natural History Museum, Baross u. 13, H-1088 Budapest, Hungary *corresponding author
\end{abstract}

ABSTRACT: Formosana renzhigangi n. sp. and Serriphaedusa (Gibbophaedusa) gerberi n. sp. are described from Yunnan Province of southern China. Additionally, new occurrence records of Papilliphaedusa kunmingensis (Chen et Zhang, 1999) are provided. The composition and diversity of Yunnan's Clausiliidae fauna, its relation to those of the adjacent zoogeographic regions, and the taxonomic status of the native genera Formosana Boettger, 1877 and Papilliphaedusa Nordsieck, 2003 are discussed.

KEY WORDS: Phaedusinae, taxonomy, zoogeography, endemism, East Asia

\section{INTRODUCTION}

The first reports on the Clausiliidae of Yunnan were published by HEUDE $(1885,1886,1890)$, and then these were soon followed by others (SYKES 1895 , DAUTZENBERG \& FISCHER 1905, ANCEY 1906) to give an interesting picture of numerous endemic species in the province. Despite that, further studies in the region were interrupted for more than nine decades. But from the end of the 20th century renewed interest and better access to even remote areas resulted in several new publications (e.g. LUO et al. 1998, CHEN \& ZHANG 1999, NORDSIECK 2001, 2003, 2007a, CHEN 2016, GREGO \& SZEKERES 2017), which outlined the diversity and character of this fauna. Here we provide descriptions of two new, apparently highly endemic clausiliids from northern Yunnan, which were collected during field trips by CHEN XIAOLEI, JOCHEN GERBER and REN ZHIGANG in 2012, and by J. GERBER, LIU CUIYOU and REN Z. in 2017.

\section{MATERIAL AND METHODS}

The samples mentioned in this paper were collected manually. Some live specimens were preserved in $95 \%$ or $70 \%$ ethanol. For clarity, in locality data the names of subprovincial administrative units (i.e., prefecture: zhou or shi, county: xian, city: shi, township: xiang or zhen, village: cun) are given in the original Chinese form. Chinese names are written in traditional order (family name first).

The type material mentioned in this paper has been deposited in the collections of the Field Museum of Natural History in Chicago (FMNH) and the Institute of Zoology of the Chinese Academy of Sciences in Beijing (IZCAS), as well as in the private collections of JOZEF GREGO, Banská Bystrica, Slovakia (GR), LI FEI, Shenyang, China (LI), and MIKLÓS SZEKERES, Budapest, Hungary (SZ). 


\section{SYSTEMATIC PART}

\section{Subfamily: Phaedusinae}

\section{Genus: Formosana Boettger, 1877}

Type species: Clausilia swinhoei Pfeiffer, 1865 (original designation)

In a shell morphology-based assessment of Chinese clausiliids NORDSIECK (2001) classified Formosana as a subgenus of Oospira Blanford, 1872 (type species: Clausilia philippiana Pfeiffer, 1847). Specifying the presence of strong, distinct plicae as the major defining character made Oospira sensu NORDSIECK $(2001,2007 \mathrm{~b})$ a taxon comprising nearly 100 species of very diverse morphology (GREGO \& SZEKERES 2008). A recent molecular phylogenetic analysis (МотосHIN et al. 2017), using both nuclear and mitochondrial DNA sequences, has shown that the species of Oospira and Formosana belong to distinct major clades of the Phaedusinae subfamily, supporting the classification of Formosana as an independent genus.
Formosana renzhigangi $\mathrm{n} . \mathrm{sp}$.

(Fig. 1)

Type material. Holotype: China, Yunnan Province, Lijiang Shi, W of Lijiang, NE side of Lake Lashi, Meiquan Cun, along a tea horse trail from the $\mathrm{N}$ end of the village $\left(26^{\circ} 54^{\prime} 18^{\prime \prime} \mathrm{N}, 100^{\circ} 08^{\prime} 57^{\prime \prime} \mathrm{E}\right.$ to $26^{\circ} 54^{\prime} 35^{\prime \prime} \mathrm{N}, 100^{\circ} 08^{\prime} 54^{\prime \prime} \mathrm{E}, 2,480-2,520 \mathrm{~m}$ a.s.l.) (Fig. 2), leg. CHEN X., J. Gerber \& REN Z. 19.06.2012 (IZCAS TM194406). Paratypes: with the same data (dry: FMNH 386275/1, IZCAS TM194407/1, GR/1, LI/2, SZ/1; in 70\% ethanol: IZCAS TM194408/1, FMNH 386276/1).

Further material. Three juvenile specimens in $95 \%$ ethanol with the same locality and collection data (FMNH 386277/3) are excluded from the paratype series.

Differential diagnosis. Small Formosana, differing from all other sinistral species of the genus in the separate lamellae superior and spiralis, as well as the deep retracted lamella subcolumellaris.

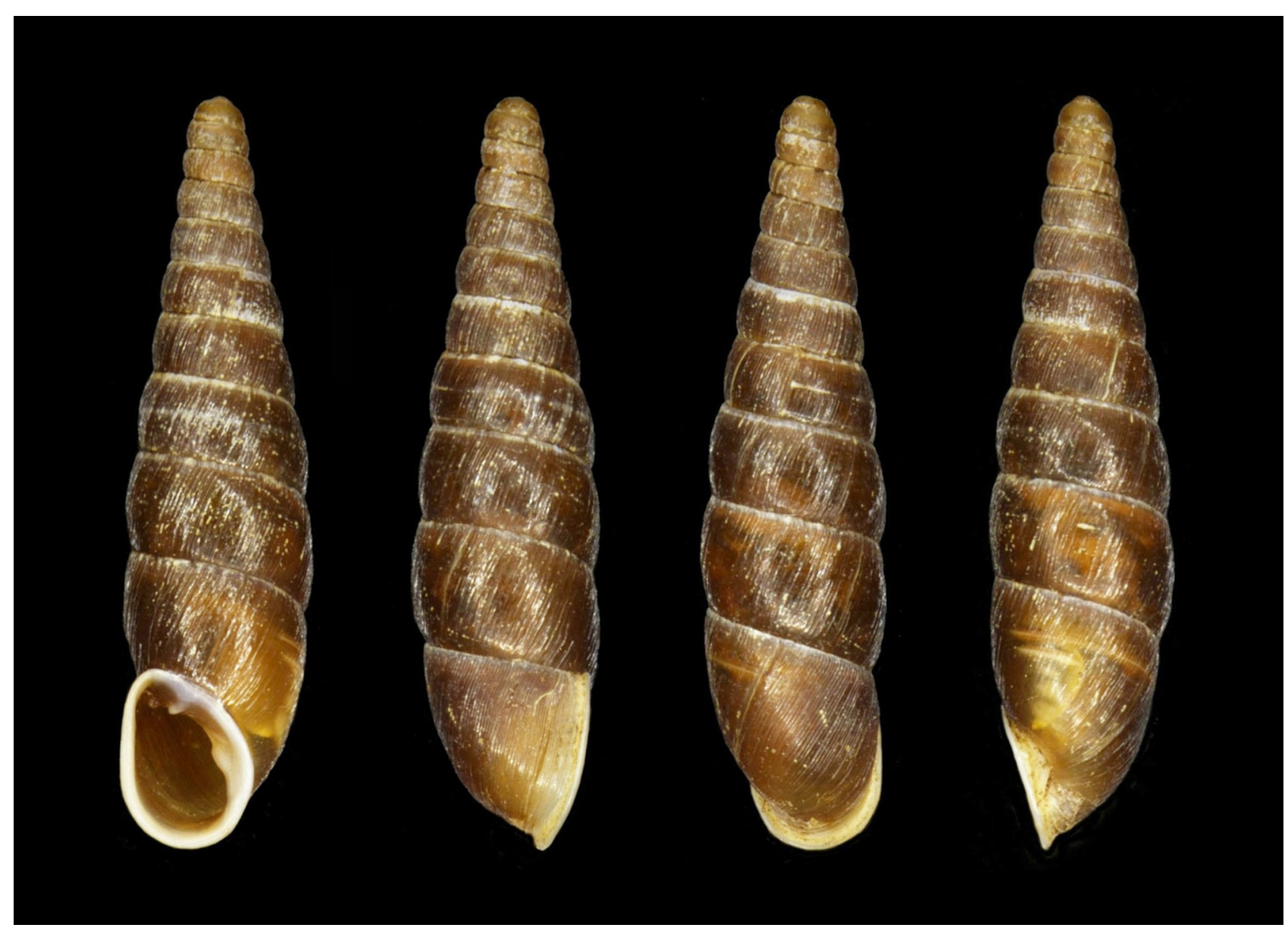

Fig. 1. Formosana renzhigangi n. sp., holotype, IZCAS TM194406 (18.8 mm) 


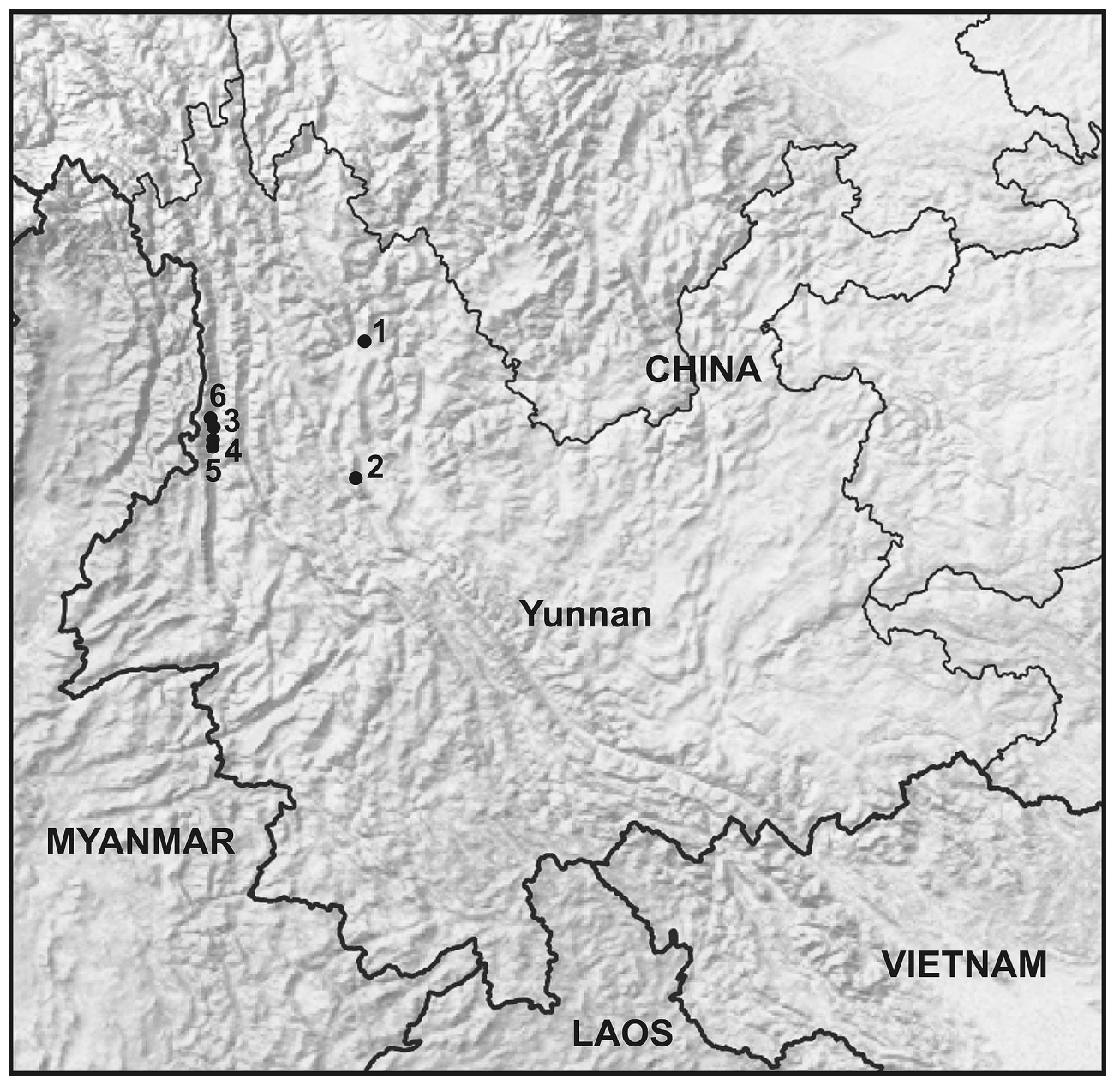

Fig. 2. Map showing the type localities of Formosana renzhigangi n. sp. (1), Serriphaedusa (Gibbophaedusa) gerberi n. sp. (2), and new localities of Papilliphaedusa kunmingensis at Nujiang Zhou, Lushui Xian, Shichidi (3), Walaya Cave (4), Denglongba (5), and Chenggan Xiang (6)

Description. The small, sinistral, chestnut brown shell with thick apex consists of 10.5 to 11.7 whorls. The dense striae on the glossy surface are stronger and sharper at the apex and the neck. The suture along the last three whorls is finely papillate. The whitish, oval aperture is detached or narrowly attached, its narrow margin is not reflexed. The lamella superior is weak, diffuse, inward broadly separated from the lamella spiralis. The steeply descending lamella inferior ends at the lower third of the aperture height. Its weakly emerged terminal part is barely visible in front view of the shell. The lamella subcolumellaris is much recessed, its end cannot be viewed through the aperture. The short plica principalis starts ventrolaterally and terminates dorsally. Lateral-ventrolaterally there are five to six parallel positioned palatal plicae, of which the uppermost is longer than the others. The clausilium plate, visible only through the transparent shell, is wide, strongly bent, its tip is slightly pointed.

Measurements. Holotype: shell height $18.8 \mathrm{~mm}$, whorl width $4.7 \mathrm{~mm}$, aperture height $4.4 \mathrm{~mm}$, aperture width $3.3 \mathrm{~mm}$; paratypes: shell height 18.5-21.1 $\mathrm{mm}$, whorl width 4.1-4.7 $\mathrm{mm}$, aperture height $4.1-$ $4.9 \mathrm{~mm}$, aperture width $3.1-4.0 \mathrm{~mm}$.

Habitat. Live specimens were collected in the ravine of a creek in broadleaf forest with dense underbrush, on soil under moist leaf litter.

Etymology. The new species is dedicated to REN ZHIGANG, one of the collectors of the type material, for his continued support of malacology in China and beyond.

Remarks. Formosana renzhigangi n. sp. is the westernmost known representative of its genus. The nearest occurring congeneric species are F. abscedens Hunyadi et Szekeres, 2016 and F. schawalleri Nordsieck, 2001 in Sichuan Province, as well as F. seguiniana (Heude, 1885) in Yunnan Province. Their localities are 350 to $450 \mathrm{~km}$ northeast of that of the new species, which differs from them in its weakly developed lamellae. The unique reduction of these structures in $F$. renzhigangi n. sp., as compared to other species of the genus, may reflect adaptation to the environmental conditions in its habitat, which is at an altitude about 1,000 m higher than those of the other Formosana species. 
Genus: Serriphaedusa Nordsieck, 2001

Type species: Clausilia serrata Deshayes, 1870 (original designation)

\section{Subgenus: Gibbophaedusa Grego et Szekeres, 2017}

Type species: Serriphaedusa (Gibbophaedusa) poppei Grego et Szekeres, 2017 (original designation)

\section{Serriphaedusa (Gibbophaedusa) gerberi n. sp.}

(Fig. 3)

Type material. Holotype: China, Yunnan Province, Dali Zhou, Dali Shi, ca. 9 air km NW of Dali old town, E slope of the Cangshan, Yingqiao Quarry $5 \mathrm{~km} \mathrm{NW}$ of the Chongshen Temple $\left(25^{\circ} 43^{\prime} 35^{\prime \prime} \mathrm{N}, 100^{\circ} 05^{\prime} 35^{\prime \prime} \mathrm{E}\right.$, 2,760-3,000 m a.s.l.) (Fig. 2), leg. J. GERBER, LIU X. \& REN Z. 20.05.2017 (IZCAS TM194405). Paratype with the same data (FMNH 386278/1).

Differential diagnosis. It differs from $S$. (G.) poppei, the only other species of the subgenus, by the smaller shell, less elongate apex, weaker basal crest, lack of sutural papillae, exposed lamella subcolumellaris, and less developed palatal plicae.
Description. The spindle-shaped, yellowish-brown shell is comprised of 11.5 to 12 whorls. The glossy surface of the shell is covered by dense striae, which gradually become fine and sharp ribs toward the apex and over the last quarter whorl. At the base there is a single, well recognisable crest. The oval, whitish aperture with a wide sinulus is detached, its narrow margin is somewhat reflexed. The lamella superior is short, weakly emerged, widely separate from the deep lamella spiralis, which is not visible through the aperture. The lamella inferior descends very steeply, terminating deep in the aperture at its quarter height. The lamella subcolumellaris reaches the peristome near the base, its end is visible in front view of the aperture. The plica principalis starts post-ventrally (above the sinulus) and terminates dorsolaterally. Ventral-ventrolaterally there are four to five palatal plicae, of which the upper- and lowermost are well developed, whereas those between them are short or even somewhat diffuse. The clausilium plate, as can be viewed through the transparent shell, is wide, backward-bent, its end is somewhat incised parietally. Measurements. Holotype: shell height $17.8 \mathrm{~mm}$, whorl width $3.8 \mathrm{~mm}$, aperture height $3.7 \mathrm{~mm}$, aperture width $2.6 \mathrm{~mm}$; paratype: shell height $16.5 \mathrm{~mm}$, whorl width $3.1 \mathrm{~mm}$, aperture height $3.4 \mathrm{~mm}$, aperture width $2.5 \mathrm{~mm}$.

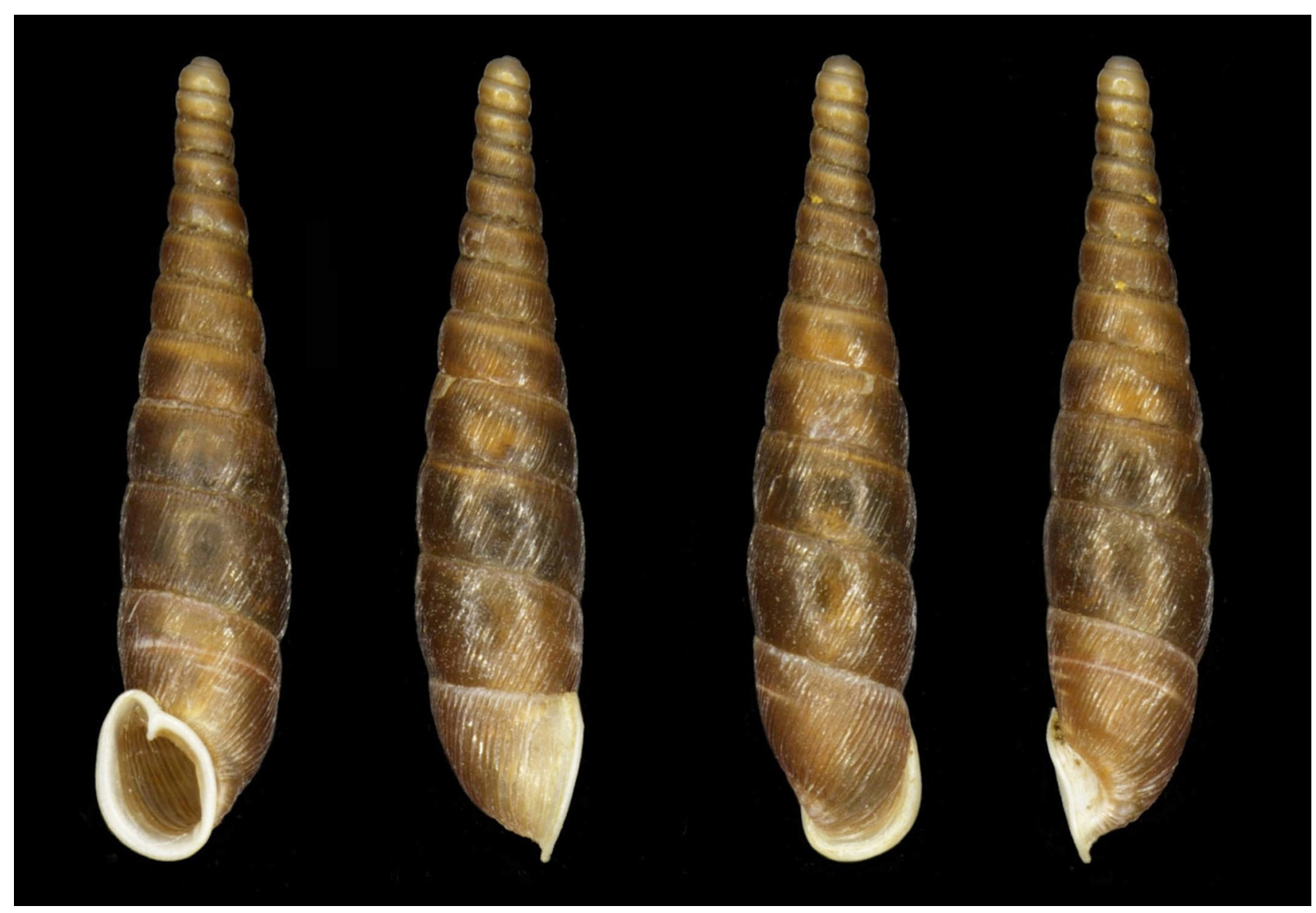

Fig. 3. Serriphaedusa (Gibbophaedusa) gerberi n. sp., holotype, IZCAS TM194405 (17.8 mm) 
Habitat. The specimens were found under rocks at an exposed, E-facing limestone talus slope.

Etymology. The new species is named after JOCHEN GERBER, one of the collectors of the type material, who kindly provided it for the study.

Remarks. The presence of basal crest, a rare character in the Phaedusinae (NORDSIECK 2001), makes the species of the subgenus Gibbophaedusa easily distinguishable from those of the other subgenera of Serriphaedusa (GREGO \& SZEKERES 2017). In S. (G.) poppei this crest is stronger than in $S$. (G.) gerberi n. sp., so that it distorts the base of the peristome. In this species a weak additional, parallel-running peripheral crest is formed, which is absent in the new species. Unlike members of the speciose nominotypical subgenus that are known only from Sichuan Province, both species of Serriphaedusa (Gibbophaedusa) seem to be endemic to Yunnan Province.

\section{Genus: Papilliphaedusa Nordsieck, 2003}

Type species: Clausilia lorraini Menke, 1856 (original designation)

Papilliphaedusa was introduced by NORDSIECK (2003) as a subgenus of Euphaedusa Boettger, 1877. However, the molecular phylogenetic analysis of MотосHIN et al. (2017) revealed that $P$. kunmingensis (Chen et Zhang, 1999) and P. porphyrea (Möllendorff, 1882), the two species included in Papilliphaedusa,

\section{THE CLAUSILIIDAE FAUNA OF YUNNAN}

Yunnan has remarkably diverse bioclimatic conditions, ranging from dry and cold alpine areas in the northwest to subtropical and tropical regions in the south (ZOMER et al. 2015). The various, climate-defined vegetation types have been divided by ZHANG et al. (2012) into seven floristic regions, of which three are particularly rich in endemics. These are the two southern regions, harbouring subtropical and tropical evergreen forests along the borders with Laos and Vietnam, as well as the north-western one, covered mainly by temperate coniferous and mixed forests. Remarkably, all but one of Yunnan's clausiliid species occur only in these three floristic regions, which hold nearly all forestlands of the province.

Up to now 31 species of Clausiliidae are known from Yunnan, of which 29 belong to the Pheadusinae, and two to the Garnieriinae. What makes this fauna particularly interesting is that two thirds of its species occur only in this province, and several of them seem to be highly endemic. Furthermore, due to its geographic position, Yunnan is a contact zone between clausiliids of Southeast and East Asian origin. The forests of the southern Xishuangbanna, Wenshan and Honghe Prefectures represent the northernmost were only distantly related to E. aculus (Benson, 1842), the type species of Euphaedusa. This extensive study focused mainly on Japanese and Taiwanese taxa, revealing that molecular phylogenies of East Asian clausiliids were often not consistent with earlier, mainly shell morphology-based classification. Although in this paper species from the Chinese mainland were only marginally dealt with, the results clearly indicate that Papilliphaedusa could not be regarded as a subgenus of Euphaedusa.

\section{Papilliphaedusa kunmingensis (Chen et Zhang, 1999)}

This endemic species of Yunnan Province has been reported only from its type locality, the Xishan Mountain W of Kunming Shi (CHEN \& ZHANG 1999). Its new occurrence records (Fig. 2) from Nujiang Zhou, Lushui Xian (leg. J. GERBER \& REN Z.) are as follows: W side of the Nu River, along Road S228 42 air $\mathrm{km} \mathrm{N}$ of Liuku Zhen, 1 air km SE of Shichidi $\left(26^{\circ} 11^{\prime} 40^{\prime \prime} \mathrm{N}, 98^{\circ} 51^{\prime} 37^{\prime \prime} \mathrm{E}, 950 \mathrm{~m}\right.$ a.s.l.); W side of the $\mathrm{Nu}$ River, 2.3 air $\mathrm{km} \mathrm{SW}$ of Tuanjie Cun, at the Walaya Cave $\left(26^{\circ} 05^{\prime} 33^{\prime \prime} \mathrm{N}, 98^{\circ} 51^{\prime} 35^{\prime \prime} \mathrm{E}, 930 \mathrm{~m}\right.$ a.s.1.); E side of the $\mathrm{Nu}$ River at the Daxingdi Bridge, 1.7 air $\mathrm{km} \mathrm{N}$ of Denglongba $\left(26^{\circ} 02^{\prime} 11^{\prime \prime} \mathrm{N}, 98^{\circ} 50^{\prime} 53^{\prime \prime} \mathrm{E}, 880 \mathrm{~m}\right.$ a.s.l.). A further sample from Chenggan Xiang $\left(26^{\circ} 15^{\prime} 19^{\prime \prime} \mathrm{N}\right.$, $\left.98^{\circ} 52^{\prime} 22^{\prime \prime} \mathrm{E}\right)$, somewhat farther north along the $\mathrm{Nu}$ River, was provided by YANG HAO (Zhangzhou City).

occurrences of some Indochinese genera (Garnieria Bourguignat, 1877, Tropidauchenia Lindholm, 1924, Selenophaedusa Lindholm, 1924), and also the southwesternmost distribution limits for genera typical to central China (Euphaedusa Boettger, 1877, Formosana Boettger, 1877, Serriphaedusa Nordsieck, 2001). Recent studies have already provided valuable information on this fauna, and future field data are expected to elucidate its diversity and zoogeographical background in more detail.

\section{ACKNOWLEDGEMENTS}

The authors are thankful to JOCHEN GERBER and YANG HAO for helpful discussions, ZOLTÁN FEHÉR for preparing the photo images, JONATHAN ABLETT for granting access to the Mollusca collection at the Natural History Museum in London, MENG KAI for assistance with depositing types at IZCAS, and three anonymous reviewers for their helpful comments. Thanks are also due to the Biodiversity Heritage Library (http://www.biodiversitylibrary.org/) for making old and rare publications accessible. 


\section{REFERENCES}

ANCEY C. F. 1906. Sur diverse mollusques de la Chine et du Japon. Journal de Conchyliologie 54: 12-23.

CHEN Y. 2016. Terrestrial molluscs in Yunnan (in Chinese). Science Press, Beijing.

CHEN D-N., ZHANG G-Q. 1999. Fauna Sinica: Mollusca, Gastropoda, Pulmonata, Stylommatophora, Clausiliidae (in Chinese). Science Press, Beijing.

DAutZenBerg P., Fischer H. 1905. Liste des mollusques récoltés par M. H. Mansuy en Indo-Chine et au Yunnan et description d'espèces nouvelles. Journal de Conchyliologie 53: 343-471.

Grego J., SZEKERES M. 2008. Oospira (Atractophaedusa) zhaoyifani spec. nov., a new clausiliid (Gastropoda, Pulmonata, Clausiliidae) from Guangxi Province, China. Basteria 72: 21-24.

Grego J., SZEKeres M. 2017. New Clausiliidae (Mollusca: Gastropoda) from China. Visaya 4: 79-93.

HEUDE P. M. 1885. Notes sur les mollusques de la vallée du Fleuve Bleu. Mémoires concernant l'histoire naturelle de l'Empire Chinois, par des pères de la Compagnie de Jésus, 3: 89-122, Bibliotheque de Mission, Shanghai.

HEUDE P. M. 1886. Diagnoses molluscorum novorum in Sinis collectorum, 1. Journal de Conchyliologie 34: 208-215, 296-302.

HEUDE P. M. 1890. Notes sur les mollusques de la vallée du Fleuve Bleu. Mémoires concernant l'histoire naturelle de l'Empire Chinois, par des pères de la Compagnie de Jésus, 4: 125-188, Bibliotheque de Mission, Shanghai.

LUO T-C., CHEN D-N., ZHANG G-Q. 1998. On three new species of Clausiliidae from China (in Chinese). Guizhou Science 16: 31-35.

Motochin R., WANG M., Ueshima R. 2017. Molecular phylogeny, frequent parallel evolution and new system of Japanese clausiliid land snails (Gastropoda: Stylommatophora). Zoological Journal of the Linnaean Society 181: 795-845. https://doi.org/10.1093/zoolinnean $/$ zlx023
NORDSIECK H. 2001. Revision of the system of the Phaedusinae from mainland China (Gastropoda: Stylommatophora: Clausiliidae), with the description of new taxa. Archiv für Molluskenkunde 129: 25-63. https://doi.org/10.1127/arch.moll/129/2001/25

NORDSIECK H. 2003. Systematic and nomenclatural notes on Phaedusinae with the description of new taxa (Gastropoda: Stylommatophora: Clausiliidae). Archiv für Molluskenkunde 132: 121-141. https://doi. org/10.1127/arch.moll/132/2003/121

NORDSIECK H. 2007a. New taxa of Phaedusinae and Garnieriinae from southern China (Gastropoda: Stylommatophora: Clausiliidae). Archiv für Molluskenkunde 136: 217-243. https://doi.org/10.1127/arch. moll/0003-9284/136/217-243

NoRDSIECK H. 2007b. Worldwide door snails. ConchBooks, Hackenheim.

SYKES E. 1895. Descriptions of new clausiliae from Japan and Yunnan. Proceedings of the Malacological Society of London 1: 261-263. https://doi.org/10.1093/oxfordjournals.mollus.a064130

ZHANG M-G., ZHOU Z-K., CHEN W-Y., SLIK J. W. F., CANNON C. H., RAES N. 2012. Using species distribution modeling to improve conservation and land use planning of Yunnan, China. Biological Conservation 153: 257-264. https://doi.org/10.1016/j.biocon.2012.04.023

Zomer R. J., XU J., Wang R., Trabucco A., Li Z. 2015. Projected impact of climate change on the effectiveness of the existing protected area network for biodiversity conservation within Yunnan Province, China. Biological Conservation 184: 335-345. https://doi.org/10.1016/j. biocon.2015.01.031

Received: September 23rd, 2019

Revised: October 30th, 2019

Accepted: November 16th, 2019

Published on-line: November 28th, 2019 